\title{
KAJIAN PENGARUH MATERI ORGANIK PADA SIFAT FISIS TANAH LUNAK
}

\author{
Asriwijanti Desiani ${ }^{1}$ \\ ${ }^{1}$ Jurusan Teknik Sipil, Fakultas Teknik, Universitas Katolik Parahyangan \\ J1. Ciumbuleuit No. 94 , Bandung \\ e-mail: asriwiyanti@gmail.com
}

\begin{abstract}
ABSTRAK
Pembangunan di atas tanah organik umumnya menimbulkan masalah karena tanah tersebut sangat lunak, basah, memiliki kuat geser rendah dan karakteristik kompresibilitas tinggi. Identifikasi keberadaan materi organik dalam tanah sebelum suatu konstruksi terlanjur dibangun dapat mengantisipasi potensi permasalahan yang mungkin terjadi dan melakukan tindakan pencegahan terhadap kerusakan. Penentuan kadar material organik yang dikandung tanah penting dilakukan untuk mencegah perkiraan jumlah yang berlebihan. Perkiraan jumlah material organik yang berlebihan dapat menuntun pada perlakuan khusus/perbaikan tanah yang mungkin sebenarnya tidak perlu dilakukan ataupun sebaliknya.

Berbagai sistem klasifikasi, baik yang berbasis botani maupun yang berbasis rekayasa Teknik Sipil dikaji kegunaannya dalam proses identifikasi tanah organik. Parameter sifat fisis tanah seperti kadar air, void ratio, bulk density, Specific gravity, permeabilitas, Batas Atterberg akan dikaji besaran dan kecenderungan perilaku apabila terdapat materi organik di dalamnya.

Tanah organik dikenali dari warnanya, coklat gelap sampai hitam dengan konsistensi spongy dan bau organis serta kadang-kadang terlihat serat tumbuhan. Tanah digolongkan tanah organik bila kandungan bahan organik antara $25-75 \%$. Kandungan bahan organik $>75 \%$ dipakai untuk mengidentifikasi gambut. Tanah organik dapat dikenali dari propertinya antara lain nilai kadar air berkisar $125-1600 \%$, void ratio $7-25$, bulk density $0.84-1.23 \mathrm{t} / \mathrm{m}^{3}$, Specific gravity $1.1-1.8$, Acidity (pH) 3.3-7.3, kadar abu 4.1-45, permeabilitas $10^{-5}-10^{-8} \mathrm{~cm} /$ detik, Batas cair (LL) 56-1500\%, Batas plastis 30-560\%. Batasan-batasan properti geoteknik untuk tanah organik umumnya masih tercampur dengan properti gambut. Kadar air dan Liquid Limit meningkat, sementara Specific gravity dan bulk density mengecil sejalan dengan meningkatnya kadar organik
\end{abstract}

Kata Kunci: Identifikasi, Tanah Organik, Kadar Organik

\section{ABSTRACT}

Construction on organic soil commonly causes certain problems as the soils are very soft, wet, with low shear strength and has high compressibility.Identification of organic matter in the soil before a construction is underway can mitigate the risk of problems that might have happened and enables preventive action to minimize damages. Determination of organic materials amount in the soil is critical to prevent overestimation. Overestimation of organic materials amount can lead to special treatment of soil which may not be necessary or vice versa.

Usage of various classification system, both based on botany and civil engineering,are assesed in the process of of soil identification. Physical soil characteristics such as water content, void ratio, bulk density, permeability, specific gravity, Atterberg's limit are tested to see certain tencdencies that might happen if there are significant amount of organic material in the soil.

Organic soil can be recognized from its dark brown to black color with its spongy consistency and other organoleptic properties such as organic smell and the occasional appearance of plant fibre. Soil can be classified as organic soil if it has between 25\%-75\% organic content. High organic content (>75\%) indicates that the soil can be classified as peat. Organic soil can be identified from its properties which are void ratio 7-25, acidity $(\mathrm{pH})$ of 3.3 to 7.3 , water content range between $125-1600 \%$, bulk density values range between $0.84-1.23 \mathrm{t} / \mathrm{m}^{3}$, ash content 4.1-4.5, permeability $10^{-5}-10^{-8} \mathrm{~cm} / \mathrm{s}$, liquid limit (LL) $56-1500 \%$, plastic limit (PL) 30 $560 \%$. There is no clear boundary between geotechnical propertiesof organic soil and properties of peat. 
Keywords: Identification, Organic Soil, Organic Content

\section{PENDAHULUAN}

\subsection{Latar Belakang}

Pembangunan di atas tanah organik umumnya menimbulkan masalah karena tanah tersebut sangat lunak, basah, memiliki kuat geser rendah dan karakteristik kompresibilitas tinggi. Kompresibilitas tinggi dan rangkak/creep umumnya meningkatkan resiko penurunan dan keruntuhan pada pondasi sedangkan karakteristik kekuatan yang rendah berkaitan dengan resiko nilai kepadatan kering maksimum yang rendah pada konstruksi jalan.

Kondisi muka air tanah pada tanah organik terletak pada atau dekat atau di atas permukaan tanah, sehingga menyebabkan akses terhadap tanah organik menjadi sulit. Kesulitan terjadi mulai saat pengambilan sampel tanah, pengujian in situ, proses konstruksi dan dilanjutkan penurunan yang sangat besar dalam jangka panjang, masalah stabilitas, serta proses stabilisasi.

Identifikasi keberadaan materi organik dalam tanah sebelum suatu konstruksi terlanjur dibangun dapat mengantisipasi potensi permasalahan yang mungkin terjadi dan melakukan tindakan pencegahan terhadap kerusakan. Penentuan kadar material organik yang dikandung tanah penting dilakukan untuk mencegah perkiraan jumlah yang berlebihan. Perkiraan jumlah material organik yang berlebihan dapat menuntun pada perlakuan khusus/perbaikan tanah yang mungkin sebenarnya tidak perlu dilakukan ataupun sebaliknya.

Pengaruh keberadaan materi organik terhadap sifat fisis tanah seperti kadar air, void ratio, bulk density, Specific gravity, permeabilitas, batas Atterberg perlu dikaji besaran dan kecenderungan perilakunya. Pengetahuan perilaku sifat fisis tanah organik sangat berguna dalam proses perbaikan tanah tersebut.

Di Indonesia tanah organik banyak ditemukan di pulau Kalimantan, Sumatera dan Papua, serta sedikit di pulau Jawa. Huat et al. (2014) mengungkapkan tanah organik di daratan Indonesia mencapai 26 juta hektar seperti terlihat pada Gambar Sedangkan Mesri dan Ajlouni (2007) meneliti penyebaran tanah gambut di dunia dan menyatakan bahwa Indonesia mempunyai lahan gambut seluas $170.000 \mathrm{~km}^{2}$ setara $14 \%$ dari seluruh luas daratan di Indonesia dan urutan ke-4 di dunia.

Korelasi Parameter dari Hasil Uji Dilatometer (Tinjauan Daerah Gedebage), 


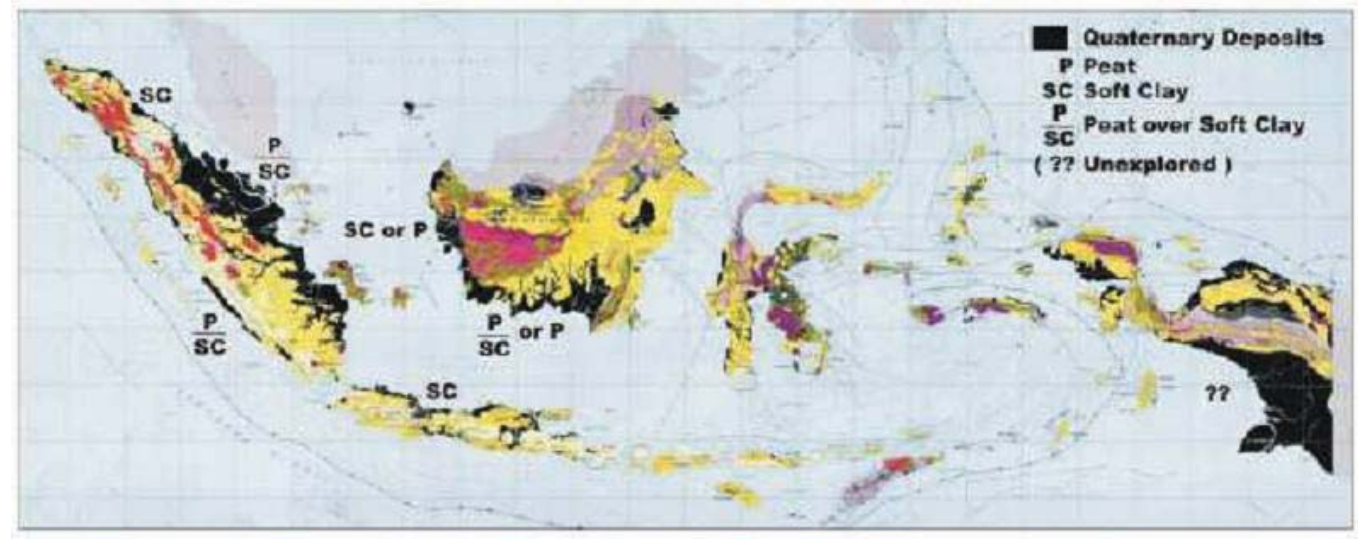

Gambar 1. Lokasi tanah organik dan gambut di Indonesia (Geo Guide, 2002).

\subsection{Maksud dan Tujuan Studi}

Maksud studi ini adalah melakukan pengkajian pengaruh materi organik terhadap sifat fisis tanah, metode identifikasi dan klasifikasi tanah organik.

Tujuan studi adalah mendapatkan batasan-batasan properti geoteknik tanah organik untuk digunakan dalam mengantisipasi masalah-masalah yang akan terjadi saat konstruksi.

\subsection{Metode Pendekatan}

Metode yang digunakan adalah studi literatur terhadap penelitian-penelitian yang pernah dilakukan sebelumnya. Data hasil uji di laboratorium, maupun data hasil uji lapangan digunakan untuk melihat pengaruh materi organik terhadap sifat fisis tanah.

\section{DEFINISI TANAH ORGANIK DAN GAMBUT}

Secara teknis material yang mengandung karbon disebut organik. Tanah organik adalah tanah yang mengandung sejumlah material organik yang berasal dari sisa tumbuhan. ASTM D4427 menjelaskan tanah dengan kandungan bahan organik lebih dari $20 \%$ disebut tanah organik dan tanah dengan kandungan bahan organik lebih dari $75 \%$ disebut Gambut. Rentang kandungan organik dijelaskan pada Tabel 1.

Tabel 1. Kandungan bahan organik (ASTM D4427)

\begin{tabular}{llll}
\hline Basic soil type & Description & Symbol & Organic content (\%) \\
\hline Clay or silt or sand & Slightly organic & 0 & $2-20$ \\
Organic soil & - & 0 & $25-75$ \\
Peat & - & $\mathrm{Pt}$ & $>75$ \\
\hline
\end{tabular}


Tanah organik sering kali dideskripsikan sebagai material yang terlihat 'fresh'dan masih dalam proses penguraian/pembusukan sehingga memiliki tanda bau, warna, dan tekstur yang berbeda. Fraksi koloid yang paling aktif secara kimia dari bahan organik adalah humus. Profil tanah organik dapat dilihat pada Gambar 2. Tanah organik umumnya memiliki warna coklat gelap sampai hitam dengan konsistensi spongy dan bau organis serta kadang-kadang terlihat serat-serat tumbuhan.

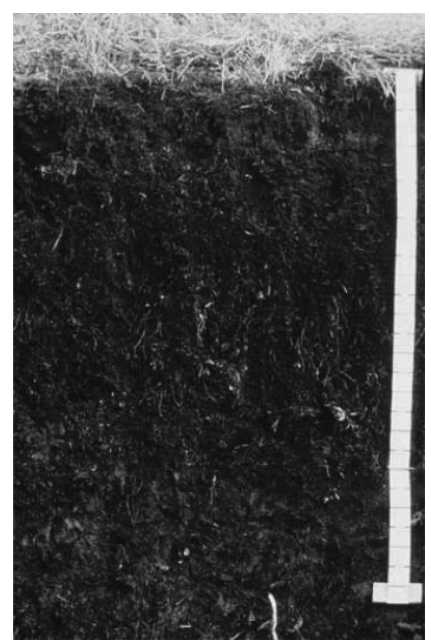

Gambar 2. Profil tanah organic (www.teara.gout.nz/en/soils/7/3/1)

Wesley (2010) mengemukakan istilah gambut digunakan pada tanah yang mengandung hampir $100 \%$ zat organik. Tanah ini secara umum dapat diketahui dari wujudnya; akan terlihat seperti benang - benang (berserat) akibat pelapukan daun dan cabang pohon. Tanah yang zat organiknya tidak mendekati $100 \%$ tetapi kadar zat organiknya tinggi disebut lempung organik. Jika bahan organik berbentuk serat maka adanya zat organik dapat langsung diketahui, tetapi jika tak berserat lebih sulit mendeteksinya. Warna tanah akibat adanya zat organik biasanya lebih gelap. Istilah berserat dan tak berserat dapat digunakan untuk menggambarkan jenis zat organik.

\section{PEMBENTUKAN TANAH ORGANIK DAN GAMBUT}

Farrell, E.R. (2012) menjelaskan bahwa tanah organik dan gambut meliputi tanah dengan rentang yang besar dalam hal morfologi dan karakteristik yang berpengaruh terhadap perilaku rekayasa. Sebenarnya kandungan organik dapat berasal dari tumbuhan atau binatang, tetapi dalam bahasan ini hanya difokuskan yang berasal dari tumbuhan. Gambut terbentuk dari akumulasi sisa-sisa tumbuhan mati dalam berbagai tahap 
pembusukan dan akumulasi ini dapat membentuk penampungan air yang mendukung pertumbuhan dan mengawetkan sisa-sisanya. Ada berbagai kondisi yang memungkinkan hal tersebut terjadi, sebagai contoh rawa dataran tinggi mendapatkan nutrisi dari air hujan yang menyebabkan pertumbuhan vegetasi tertentu dan terbuat hampir seutuhnya dari material organik. Sementara itu jenis rawa lain mendapat pasokan dari permukaan tanah dan aliran air tanah yang mengandung campuran partikel anorganik.

Huat et. Al. (2014) menjelaskan di area tropis, seperti Malaysia dan Indonesia, endapan gambut bisa terdapat baik di dataran tinggi maupun dataran rendah. Secara umum, mereka disebut gambut cekungan dan gambut lembah. Meskipun begitu, gambut dataran rendah atau gambut lembah umumnya lebih luas dan terbentuk di daerah cekungan dengan ketinggian rendah dan drainase buruk pada daerah pesisir. Gambut cekungan umumnya terdapat pada tepi bagian dalam rawa bakau di sepanjang pesisir. Badan gambut individual dapat berkisar dari beberapa hektar sampai 100.000 hektar dan umumnya memiliki permukaan berbentuk kubah. Secara umum, gambut jenis ini dikelompokkansebagai ombrogenous dan memiliki kandungan nutrisi yang rendah (oligotrofik). Sebagai akibat dari geomorfologi pesisir dan aluvial, tanah gambut cekungan sering memiliki bentuk yang memanjang dan tidak teratur, dibanding berbentuk genangan bundar ideal. Kedalaman gambut umumnya lebih dangkal di dekat pesisir dan meningkat kedalamannya makin jauh ke daratan, secara lokal melampaui kedalaman 20 meter. Tanah gambut pesisir secara umum memiliki ketinggian di atas aliran sungai yang berdekatan. Kemiringan yang curam ditemukan pada daerah sekelilingnya, sedangkan bagian tengah dataran gambut hampir rata. Yogeswaran (1995) memberi gambaran tentang potongan melintang dan memanjang dari gambut cekungan Error! Reference source not found.

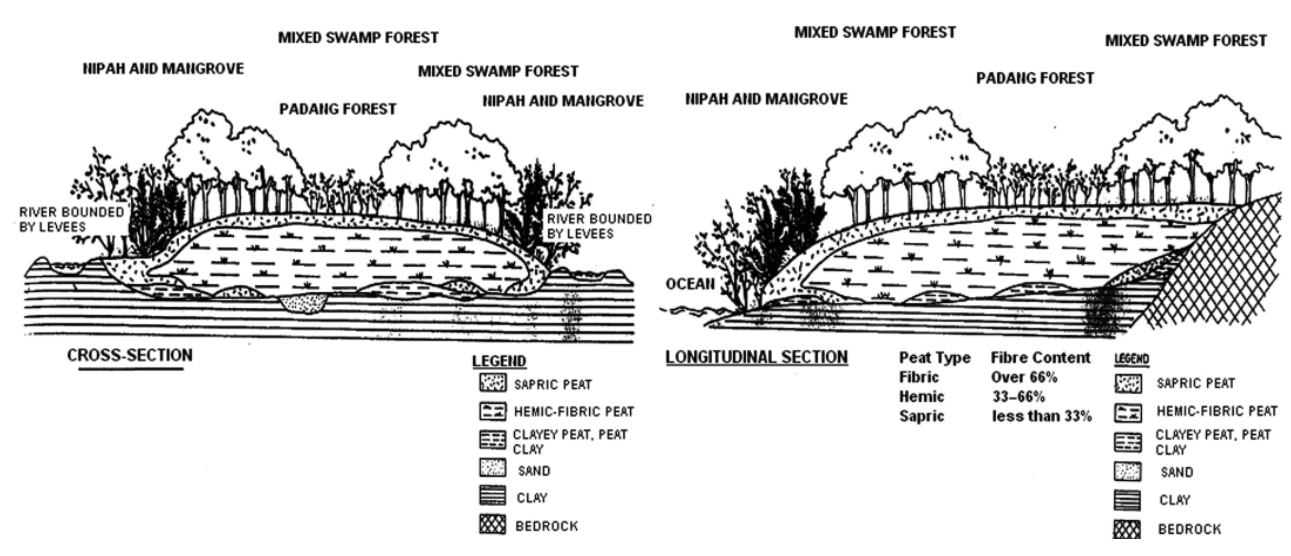

Gambar 3. Potongan melintang dan memanjang gambut cekungan (Yogeswaran, 1995) 
Air memainkan peran mendasar dalam perkembangan dan pemeliharaan gambut tropis. Keseimbangan curah hujan dan evapotranspirasi sangat penting dalam kesinambungan gambut. Curah hujan dan topografi permukaan mengatur sifat hidrologis dari tanah gambut secara keseluruhan.Dataran gambut juga dikenal sebagai rawa-rawa atau rawa gambut karena permukaan air nya yang berada di atas atau dekat dengan permukaan gambut sepanjang tahun dan mengalami fluktuasi sesuai dengan intensitas serta frekuensi hujan. Rawa gambut adalah bagian penting dari dataran rawa dunia dimana hubungan dinamis antara daratan dan air, aliran air, siklus nutrisi, dan energi dari matahari bergabung menjadi suatu ekosistem unik yang dibentuk dari hidrologi, tanah, dan vegetasi. Penyusunan lapisan gambut dan derajat dekomposisi bergantung secara prinsip pada komposisi lokal gambut dan derajat penggenangan air. Leete (2006) menjelaskan 3 tahap pembentukan rawa gambut berikut ini yang terdapat dalam Gambar 4.

- Tahap 1: Air hujan dan air dari aliran sungai di dekatnya tertahan di cekungan

- Tahap 2: Perkembangan tumbuhan rawa
a) Akumulasi bahan organik dari daun dan sisa pohon (bersifat serat)
b) Penguraian melambat karena berkurangnya aliran udara sehingga terjadi kondisi anoxic (kurang oksigen)
c) Degradasi oleh mikroba melambat
d) Warna air berubah menjadi hitam kecoklatan
e) $\mathrm{pH} 2.5-4.5$
f) Pengendapan Alluvial melambat

- Tahap 3: Perkembangan hutan rawa air tawar

Tanah gambut terbentuk setelah bertahun-tahun, perkiraan $2.0-4.5 \mathrm{~mm}$ endapan gambut per tahun. 

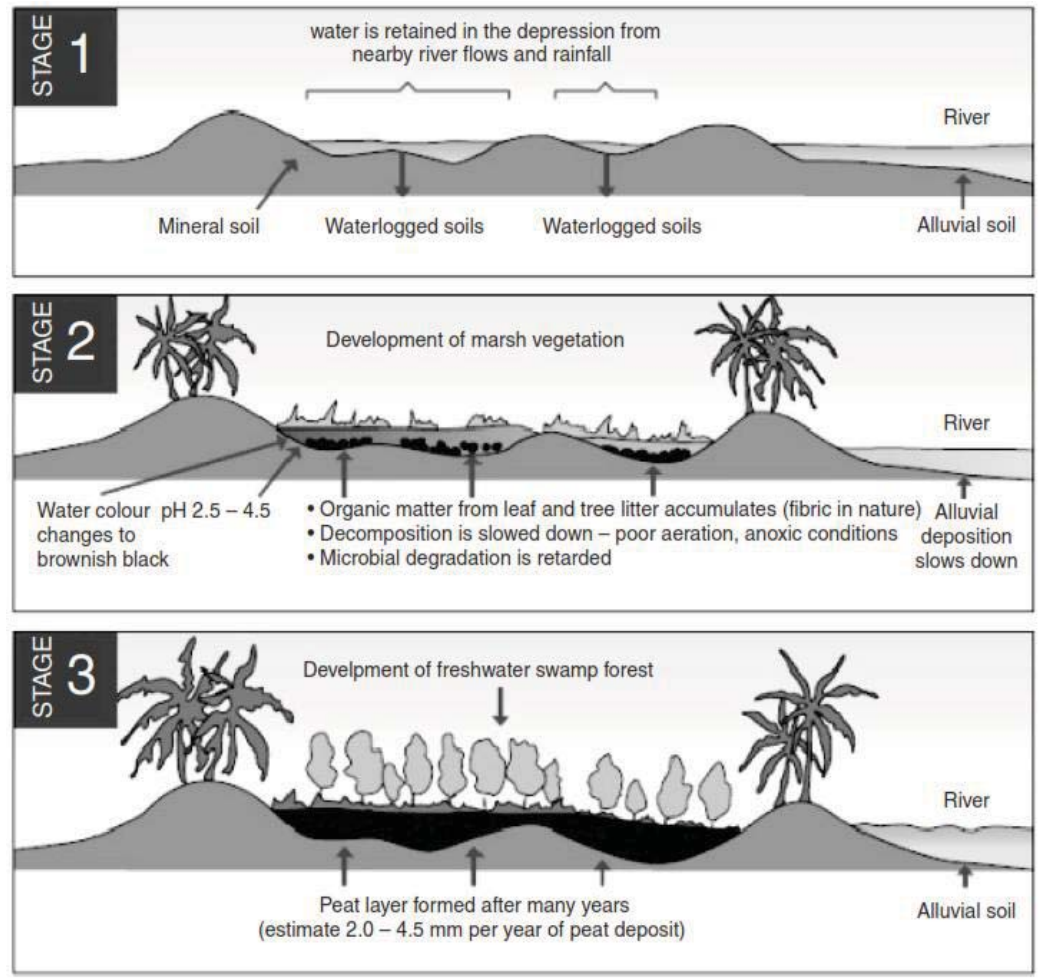

Gambar 4. Pembentukan rawa gambut (after Leete. 2006)

\section{KLASIFIKASI DAN IDENTIFIKASI TANAH ORGANIK}

Sistem klasifikasi untuk endapan tanah organik dan gambut terbagi dalam dua kategori besar, yaitu: sistem klasifikasi berbasis botani dan ekologi dan sistem klasifikasi berbasis engineering/rekayasa.

\subsection{Sistem Klasifikasi dan Identifikasi Berbasis Botani}

Sistem Von Post yang dikembangkan untuk penggunaan hortikultura, agrikultura dan kehutanan memiliki uji 'squeeze' yang sederhana. Uji tersebut menilai derajat pembusukan dari gambut. Terdapat 10 derajat pembusukan (H1 sampai H10) yang ditentukan berdasarkan air yang muncul ketika tanah diperas memakai tangan.

Von Post (1922) awalnya mengajukan sistem klasifikasi berdasarkan derajat pembusukan, namun kemudian dikembangkan termasuk properti kadar air, kadar serat, dan keberadaan sisa kayu seperti terlihat pada Tabel 2. 
Tabel 2. Skala Von Post (Rahardjo, P.P, 2004).

\begin{tabular}{|c|c|}
\hline Symbol & Description \\
\hline H1 & $\begin{array}{l}\text { Completely undecomposed peat which, when squeezed, releases almost clear } \\
\text { water. Plant remains easily identifiable. No amorphous material present }\end{array}$ \\
\hline $\mathrm{H} 2$ & $\begin{array}{l}\text { Almost entirely undecomposed peat which, when squeezed releases clear or } \\
\text { yellowish water.Plant remains still easily identifiable. No amorphous material } \\
\text { present. }\end{array}$ \\
\hline $\mathrm{H} 3$ & $\begin{array}{l}\text { Very slightly decomposed peat which, when squeezed, releases muddy brown } \\
\text { water, but from which no peat passes between the fingers. Plant remains still } \\
\text { identifiable and no amorphous material present. }\end{array}$ \\
\hline $\mathrm{H} 4$ & $\begin{array}{l}\text { Slightly decomposed peat which, when squeezed, releases very muddy dark } \\
\text { water. No peat is passed between the fingers but the plant remains are slightly } \\
\text { pasty and have lost some of their identifiable features. }\end{array}$ \\
\hline H5 & $\begin{array}{l}\text { Moderately decomposed peat which, when squeezed, releases very "muddy" } \\
\text { water with a very small amount of amorphous granular peat escaping between the } \\
\text { fingers. The structure of the plant remains is quite indistinct although it is still } \\
\text { possible to recognize certain features. The residue is very pasty. }\end{array}$ \\
\hline H6 & $\begin{array}{l}\text { Moderately highly decomposed peat with a very indistict plant structure. When } \\
\text { squeezed, about one-third of the peat escapes between the fingers. The residue is } \\
\text { very pasty but shows the plant structure more distinctly than before squeezing. }\end{array}$ \\
\hline $\mathrm{H} 7$ & $\begin{array}{l}\text { Highly decomposed peat. Contains a lot of amorphous material with very faintly } \\
\text { recognizable plant structure. When squeezed, about one-half of the peat escapes } \\
\text { between the fingers. The water, if any is released, is very dark and almost pasty. }\end{array}$ \\
\hline $\mathrm{H} 8$ & $\begin{array}{l}\text { Very highly decomposed peat with a large quantity of amorphous material and } \\
\text { very indistinct plant structure. When squeezed, about two-thirds of the peat } \\
\text { escapes between the fingers. A small quantity of pasty water may be released. } \\
\text { The plant material remaining in the hand consists of residues such as roots and } \\
\text { fibres that resist decomposition. }\end{array}$ \\
\hline H9 & $\begin{array}{l}\text { Practically fully decomposed peat in which there is hardly any recognizable plant } \\
\text { structure. When squeezed it is a fairly uniform paste. }\end{array}$ \\
\hline \multirow[t]{2}{*}{ H10 } & $\begin{array}{l}\text { Completely decomposed peat with no discernible plant structure. When } \\
\text { squeezed, all the wet peat escapes between the fingers. }\end{array}$ \\
\hline & Wetness \\
\hline B1 & Dry peat \\
\hline B2 & Low moisture content $\mathrm{w}<500 \%$ \\
\hline B3 & Moderate moisture content $500 \%<\mathrm{w}<1000 \%$ \\
\hline B4 & High moisture content $1000 \%<\mathrm{w}<2000 \%$ \\
\hline \multirow[t]{2}{*}{ B5 } & Very high moisture content $\mathrm{w}>2000 \%$ \\
\hline & Fibres \\
\hline F0 & Moderare content \\
\hline \multirow[t]{2}{*}{ F1 } & High content \\
\hline & Woodiness \\
\hline W0 & Moderate content \\
\hline W1 & Low content \\
\hline
\end{tabular}


Penggunaan klasifikasi Von Post yang telah dimodifikasi dapat mengikuti detail berikut:

1. Kedalaman sampel (dalam $\mathrm{cm})$

2. Jenis gambut berdasarkan pengenalan sifat yang menonjol dari tanaman asli: (S) Sphagnum, (C) Carex, (Er) Eriophorum, (Eq) Equisetum, (Ph) Phragmites, (Sch) Scheuchzeria, (N) Shrubs, (L) Wood

3. Kadar air (lihat Tabel 2) Catatan: B1 mengindikasikan tanah kering

4. Kadar serat diberi simbol $\mathrm{F}$ untuk serat halus dan $\mathrm{R}$ untuk serat kasar. Serat digolongkan kasar bila serat memiliki diameter lebih besar dari $1 \mathrm{~mm}$. Nilai 0-3 digunakan untuk jumlah serat.

Contoh: $F_{0}\left(R_{0}\right)=$ nol, tak ada kandungan serat, $F_{3}\left(R_{3}\right)=$ kandungan serat tinggi.

5. Derajat pembusukan diberi simbol $\mathrm{H}$, dari 1 sampai 10 untuk menggambarkan derajat pembusukan (lihat Tabel 2.).

Contoh: $\mathrm{H} 1=$ gambut dengan pembusukan sempurna/ selesai)

6. Keberadaan sisa kayu diberi symbol W, dari 1 sampai 3, makin banyak kandungan sisa kayu makin besar angkanya.

Contoh: W3 = kandungan tinggi

7. Informasi lain berkenaan dengan keberadaan sesuatu ditambahkan di akhir menggunakan simbol yang sesuai dan singkatan.

\subsection{Sistem Klasifikasi Tanah Organik pada rekayasa Teknik Sipil}

Berbagai organisasi di dunia bertanggung jawab atas sistem klasifikasi tanah yang digunakan oleh bidang Teknik Sipil. Tujuan dari sistem klasifikasi adalah menentukan tanah ke dalam suatu kelompok kategori tertentu dimana tanah didalam kategori tersebut diharapkan memperlihatkan perilaku rekayasa yang sama. Berbagai sistem klasifikasi berbasis rekayasa Teknik Sipil dari berbagai organisasi akan dikaji berikut ini:

American Society for Testing Material (ASTM D2487) menggolongkan tanah menurut Unified Soil Classification System (USCS). Sistem ini berdasarkan distribusi ukuran butir dan batas-batas Atterberg yaitu: Batas Cair (LL); Batas Plastis (PL) dan Indeks Plastisitas (PI=LL-PL). Sistem klasifikasi membedakan dua jenis tanah utama, tanah butir kasar dan tanah butir halus yang didasarkan apakah \% tanah lebih halus dari $0.075 \mathrm{~mm}$ jumlahnya lebih besar atau sama dengan 50\% (tanah butir halus), atau lebih sedikit dari 50\% (tanah butir kasar). Sistem ini menganggap tanah organik adalah subgroup tanah butir halus. Lebih khusus lagi tanah digolongkan mengandung bahan 
organik berdasarkan perbandingan batas cair (LL) pada tanah yang di oven dan tidak di oven. Bila $\mathrm{LL}_{\text {oven }} / \mathrm{LL}_{\text {non oven }}<0.75$ maka tanah mengandung material organik dan diklasifikasi sebagai OL atau OH tergantung apakah $\mathrm{LL}<50$ (tergolong OL) atau LL $>50$ (tergolong $\mathrm{OH}$ ).

ASTM juga mengklasifikasi highly organic soils yang diberi group simbol Pt dan nama group Peat (Gambut). Proses klasifikasi tidak memakai pengukuran atau uji apapun, hanya didasarkan kelaziman dari warna dan bau material organik.

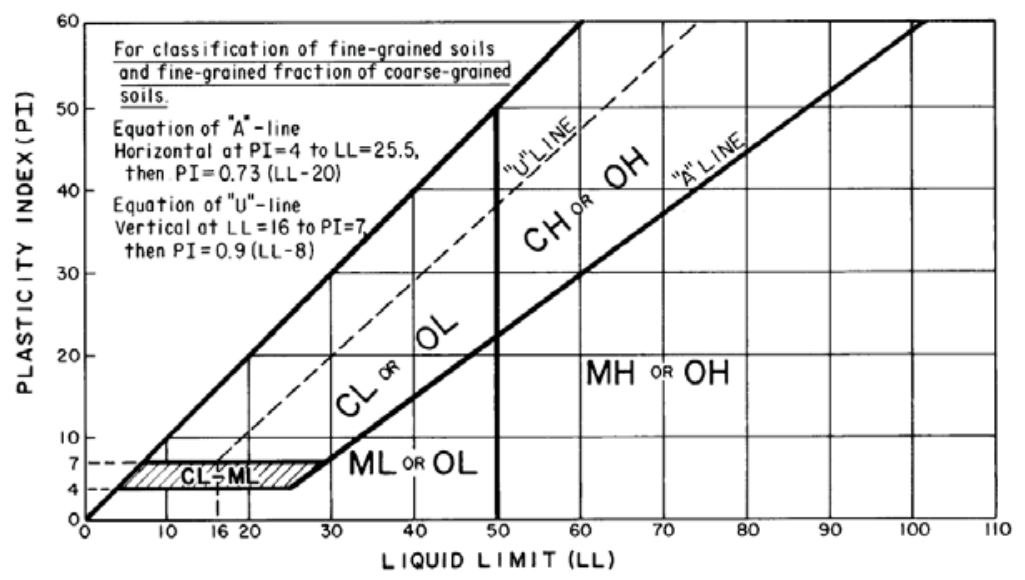

Gambar 5. Plasticity chart (ASTM D2487).

American Society for Testing Material (ASTM D4427) melengkapi klasifikasi gambut lebih detail dengan membedakan material organik berdasarkan kadar serat, kadar abu, keasaman, penyerapan dan komposisi botani yang dikandungnya. Metode penentuan kadar serat berdasarkan ASTM D1977, kadar abu berdasarkan ASTM D2974, keasaman berdasarkan ASTM D2976, dan penyerapan air berdasarkan ASTM D2980 yang batasanbatasan nya dapat dilihat pada Error! Reference source not found..

Menurut standar American Society for Testing and Materials (ASTM), klasifikasi gambut sudah dipersempit menjadi tiga kelas yang didasarkan pada kandungan serat, kandungan abu dan keasaman tanah. Dalam klasifikasi kandungan serat, gambut dibagi menjadi tiga kelompok, yaitu (i) fibric (berserat, paling tidak terdekomposisi, mengandung lebih dari 67\% serat) (ii) hemic (cukup berserat, cukup terdekomposisi) dan (iii) sapric (tak berbentuk, paling terdekomposisi, mengandung kurang dari 33\% serat).

Gambut berserat memiliki kandungan organik dan serat yang tinggi, dengan derajat humifikasi yang rendah. Tanah jenis ini terdiri dari materi organik berserat yang tidak membusuk. Gambut berserat juga mudah diidentifikasi dan sangat asam. Gambut Sapric mengandung materi yang sudah banyak membusuk. Serat tumbuhan aslinya 
kebanyakan sudah menghilang dan kemampuannya untuk menyerap air secara umum kurang bila dibandingkan dengan gambut berserat atau hemic. Gambut sapric secara umum berwarna abu sangat gelap sampai hitam dan sifat fisisnya cukup stabil. Bila dibandingkan dengan endapan gambut berserat, endapan gambut sapric lebih menunjukan angka pori, permeabilitas, kompresibilitas, dan sudut geser yang lebih rendah serta koefisien tekanan tanah at rest yang lebih tinggi. Gambut hemic memiliki karakteristik menengah di antara gambut sapric dan berserat.

Tabel 3. Klasifikasi Gambut (ASTM).

\begin{tabular}{ll}
\hline Kadar serat & Fibric: Gambut dengan serat $>67 \%$ \\
\hline (ASTM D1977) & Hemic: Gambut dengan serat antara $33 \%-67 \%$ \\
\hline & Sapric: Gambut dengan serat $<33 \%$ \\
\hline Kadar abu & Low ash: Gambut dengan abu $<5 \%$ \\
\hline (ASTM D2974) & Medium ash: Gambut dengan abu antara $5 \%-15 \%$ \\
\hline & High ash: Gambut dengan abu $>15 \%$ \\
\hline Keasaman & Highly acidic: Gambut dengan $\mathrm{pH}<4.5$ \\
\hline (ASTM D2976) & Moderate acidic: Gambut dengan $\mathrm{pH}$ antara $4.5-5.5$ \\
\hline & Slightly acidic: Gambut dengan $\mathrm{pH}$ antara $5.5-<7.0$ \\
\hline & Basic: Gambut dengan pH = 7.0 atau $>7.0$ \\
\hline & \\
\hline Penyerapan air & Extremely absorbent: kapasitas gambut menahan air $>1500 \%$ \\
\hline (ASTM D2980) & Highly absorbent: kapasitas gambut menahan air $800-1500 \%$ \\
\hline & Moderately absorbent: kapasitas gambut menahan air $300-800 \%$ \\
\hline & Slightly absorbent: kapasitas gambut menahan air $<300 \%$ \\
\hline Komposisi Botani & Berdasarkan genus tanaman yang dominan teridentifikasi secara visual \\
\hline & minimal mengandung $75 \%$ serat \\
\hline
\end{tabular}

American Association of State Highway and Transportation Officials (AASHTO) Designation: M 145-91 (2012) mengklasifikasi tanah dalam 7 Group, dari A-1 sampai A-7 berdasarkan analisa ukuran butir dan batas-batas Atterberg. Highly organic soils (peat or muck)/Tanah berkadar organik tinggi diklasifikasikan pada group A-8. Klasifikasi material ini didasarkan pada pengamatan visual dan tidak bergantung pada analisa ukuran butir dan batas-batas Atterberg. Material ini terutama terdiri dari bahan organik yang sebagian membusuk/dalam proses penguraian, umumnya mempunyai tekstur berserat, berwarna hitam atau coklat tua dan berbau pembusukan. Material organik tidak sesuai digunakan sebagai timbunan dan material subgrades. Material ini memiliki pemampatan tinggi dan kekuatan rendah. 
Pao-Tsung huang et al. (2009) dari Purdue University mengajukan suatu sistem klasifikasi tanah organik dan gambut untuk Federal Highway Administration (FHWA) seperti terlihat pada Error! Reference source not found. berikut ini. Tanah diklasifikasi ke dalam empat kelompok berdasarkan kadar organik:

- Tanah mineral bila kadar organik $\leq 3 \%$

- Tanah mineral mengandung organik bila kadar organik $>3 \%$ tetapi $\leq 15 \%$

- Tanah organik bila kadar organik $>15 \%$ dan $\leq 30 \%$.

- Tanah organik berkadar tinggi atau Gambut bila kadar organik $>30 \%$

Uji LOI disarankan digunakan untuk menilai kadar organik karena penggunaannya dalam praktek rekayasa geoteknik cukup praktis. Bila LOI lebih kecil dari 3\% tidak dibutuhkan uji lanjutan, tanah diklasifikasikan sebagai tanah mineral (misal: kerikil, pasir, lanau, lempung). Tanah dengan nilai LOI 3\% - 15\% membutuhkan uji lanjutan, yaitu uji colorimetric dan penentuan liquid limit ratio (LLR). Uji lanjutan dimaksudkan untuk menentukan apakah tanah tergolong tanah mineral saja atau tanah mineral mengandung organik. Proses uji lanjutan dapat dilihat pada Error! Reference source not found.

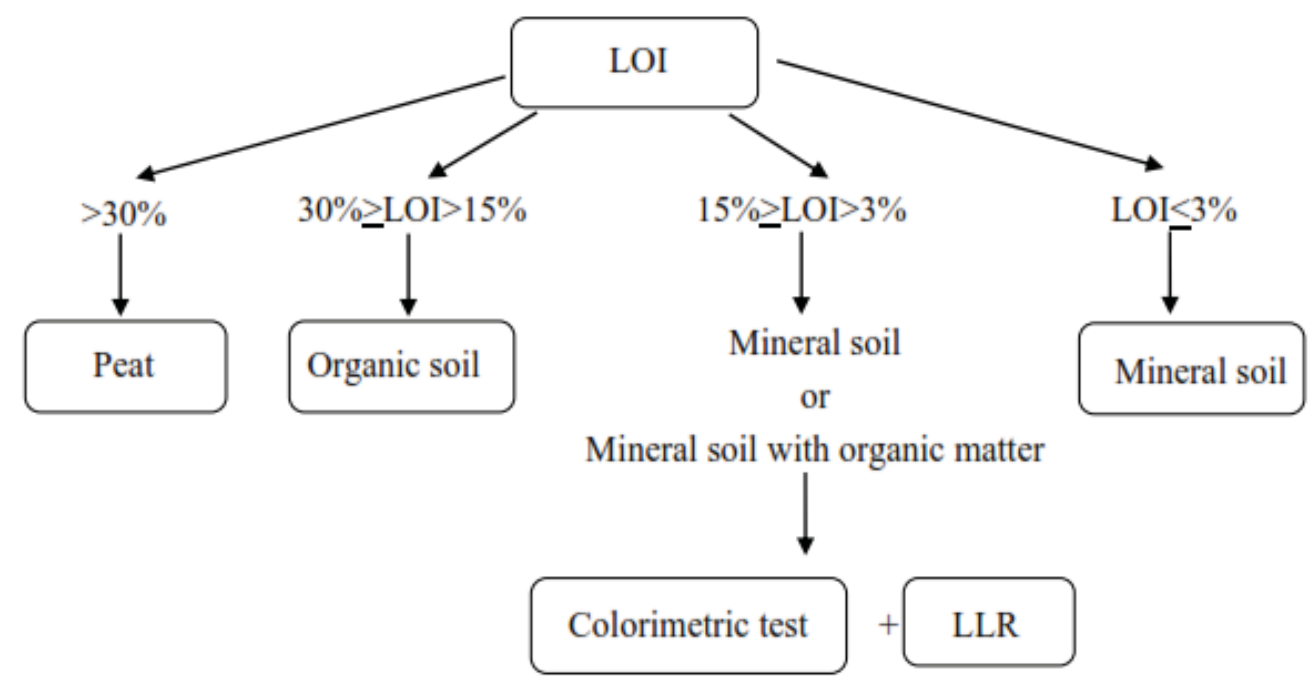

\section{Gambar 6. Bagan alir untuk klasifikasi tanah organik (FHWA/IN/JTRP-2008/2)}

Tanah yang digolongkan butir kasar diperiksa terhadap persen lolos saringan no. 200 , bila jumlah $\mathrm{F}_{200}$ lebih kecil dari $12 \%$ dilakukan uji colorimetric. Warna cairan supernatant dibandingkan dengan pelat warna standar bahan organik no.3. Bila warna cairan supernatant lebih terang dari warna no.3 maka tanah diklasifikasikan sebagai tanah 
mineral. Bila lebih gelap tanah diklasifikasikan sebagai tanah mineral mengandung material organik.

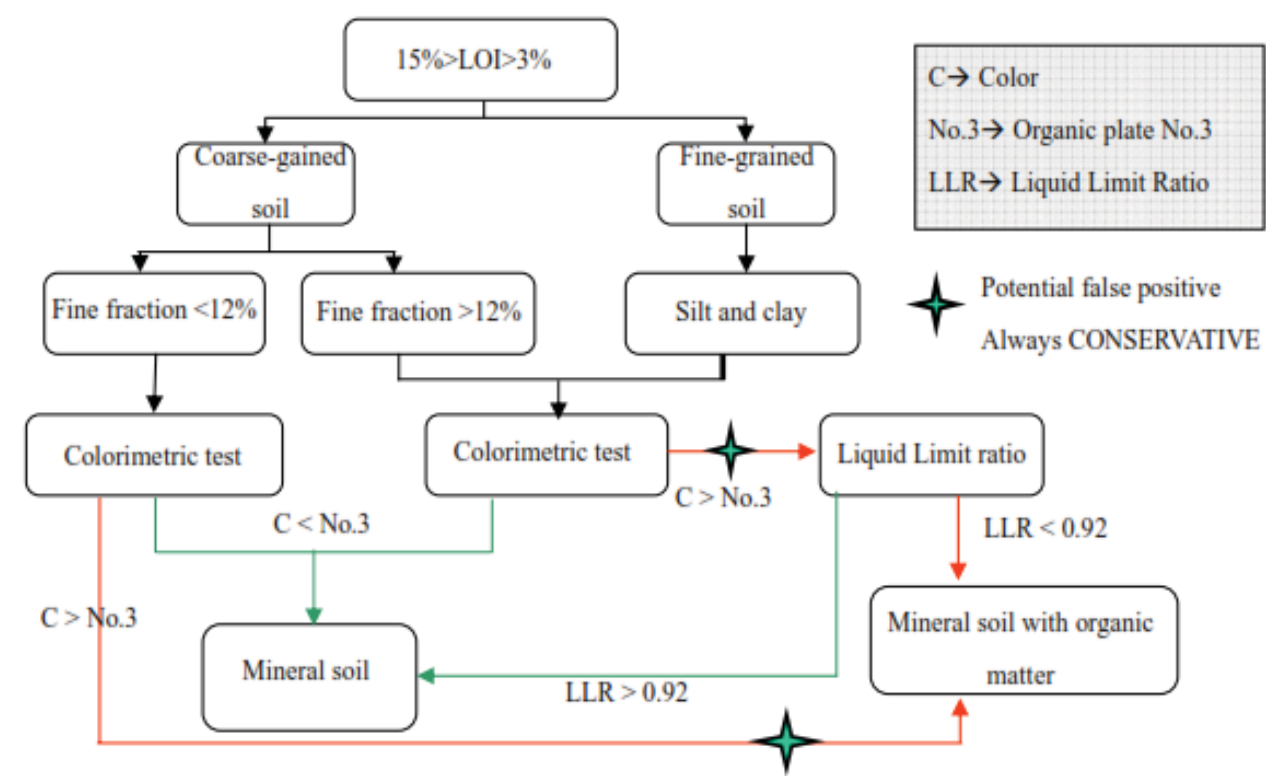

Gambar 7. Uji lanjutan klasifikasi tanah mineral

(FHWA/IN/JTRP-2008/2)

Tanah yang digolongkan butir kasar diperiksa terhadap persen lolos saringan no. 200 , bila jumlah $\mathrm{F}_{200}$ lebih besar dari $12 \%$ dilakukan uji colorimetric. Warna cairan supernatant dibandingkan dengan pelat warna standar bahan organik no.3. Bila warna cairan supernatant lebih terang dari warna no.3 maka tanah diklasifikasikan sebagai tanah mineral. Bila lebih gelap tanah diuji liquid limit ratio. Nilai LLR $<0.92$ tanah digolongkan sebagai tanah mineral mengandung material organik. Nilai LLR $>0.92$ tanah digolongkan sebagai tanah mineral.

Prosedur untuk tanah butir halus (klasifikasi AASHTO; A-4, A-5, A-6, A-7) sama dengan prosedur tanah butir kasar dengan $\mathrm{F}_{200}>12 \%$.

Sistem klasifikasi yang diajukan oleh Pao-Tsung huang et al. (2009) dapat dikombinasikan penggunaannya dengan sistem klasifikasi AASHTO maupun USCS yang berlaku seperti terlihat pada Tabel Error! No text of specified style in document.. Simbol yang digunakan konsisten dengan simbol pada sistem klasifikasi AASHTO maupun USCS, sedangkan nama yang digunakan mengacu pada ASTM D2487 (1999). 
Tabel Error! No text of specified style in document.. Klasifikasi tanah organik dan gambut

(FHWA/IN/JTRP-2008/2)

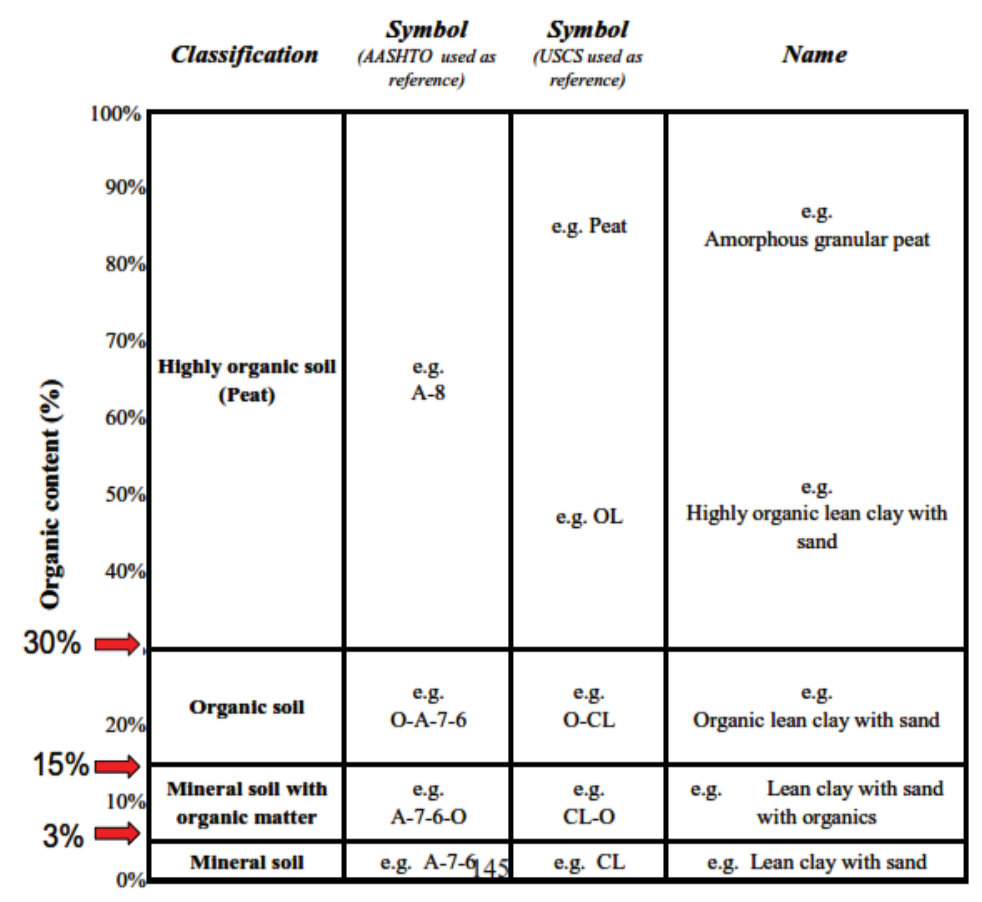

Sistem Eurocode merujuk dua standar yang meliputi identifikasi dan klasifikasi tanah, yaitu EN ISO 14688-1:2002 dan EN ISO 14688-2:2004.

EN ISO 14688-1:2002 mendefinisikan materi organik sebagai materi yang terdiri dari materi organik tumbuhan dan/atau hewan serta turunan produk dari material tersebut seperti humus (Tabel 5.).

BS 5930:1999 (BSI, 1999) memiliki kategori deskripsi yang terdiri dari berserat, berserat semu, gambut amorphous. Gyttja adalah istilah Scandinavia untuk bahan organik terdeposit di dasar danau atau laut. Derajat pembusukan gambut pada EN ISO14688-1:2002 dinilai atas dasar uji 'squeeze' yang sederhana (Tabel 6.) yang merupakan penyederhanaan dari sistem von Post dimana derajat pembusukan (Hn) diukur dalam skala 1-10. Hal ini merupakan modifikasi yang sudah dimasukkan dalam standar ASTM (Tabel 2.) Sistem von Post umumnya digunakan bila diperlukan deskripsi gambut secara rinci. 
Tabel 5. Identifikasi dan deskripsi tanah organik (EN ISO 14688-1:2002)

\begin{tabular}{ll}
\hline Term & Description \\
\hline Fibrous peat & $\begin{array}{l}\text { Fibrous structure, easily recognisable plant structure, retains some } \\
\text { strength }\end{array}$ \\
\hline Pseudo-fibrous peat & Recognisable plant structure, no strength of apparent plant material \\
\hline Amorphous peat & No visible plant structure, mushy consistency \\
\hline Gyttja & $\begin{array}{l}\text { Decomposed plant and animal remains; may contain inorganic } \\
\text { constituens }\end{array}$ \\
\hline Humus & $\begin{array}{l}\text { Plant remains, living organism and their excretions, together with } \\
\text { inorganic constituens, form the topsoil }\end{array}$ \\
\hline
\end{tabular}

Tabel 6. Derajat pembusukan gambut berdasarkan uji squeeze (EN ISO14688-1:2002)

\begin{tabular}{llll}
\hline Term & Decomposition & Remains & Squeeze \\
\hline Fibrous & None & $\begin{array}{l}\text { Clearly } \\
\text { recognisable }\end{array}$ & Only water No solids \\
\hline Pseudo-fibrous & Moderate & Recognisable & $\begin{array}{l}\text { Turbid Water }<50 \% \\
\text { solids }\end{array}$ \\
\hline Amorphous & Full & Not Recognisable & Paste $>50 \%$ solids \\
\hline
\end{tabular}

EN ISO 14688-2:2004 mengelompokan tanah dengan kandungan organik lebih dari $20 \%$ sebagai tanah berkadar organik tinggi (Tabel 7.7). Namun tidak ada penentuan kapan tanah organik menjadi gambut atau gambut berlempung menjadi lempung bergambut. BS 5930:1999 (BSI, 1999) memberikan sistem klasifikasi tanah dimana kadar organik adalah unsur sekunder dan tidak digolongkan sebagai gambut.

Tabel 7. Klasifikasi tanah berdasarkan kadar organik (EN ISO 14688-2:2004)

\begin{tabular}{ll}
\hline Soil & Organic content $(\leq \mathbf{2 m m}) \mathbf{\%}$ dry mass \\
\hline Low organic & 2 to 6 \\
\hline Medium organic & 6 to 20 \\
\hline High organic & $>20$ \\
\hline
\end{tabular}

\section{METODE PENENTUAN KANDUNGAN ORGANIK}

Tersedia banyak metode untuk mengetahui keberadaan dan jumlah kandungan organik pada tanah. Dalam kajian ini hanya dibahas 3 metode, yaitu: Hilang pijar (Loss 
on ignition /LOI), Hydrogen peroxide $\left(\mathrm{H}_{2} \mathrm{O}_{2}\right)$ dan Colorimetric. Pada metode LOI dan $\mathrm{H}_{2} \mathrm{O}_{2}$, jumlah bahan organik pada tanah diukur berdasarkan jumlah bahan organik yang hilang. Persentase berat yang hilang pada kondisi kering menyatakan kandungan organik.

\subsection{Metode Loss on Ignition /LOI}

Metode Loss on ignition adalah metode dekomposisi bahan organik memakai panas. Pemanasan pada suhu tinggi digunakan untuk menghilangkan bahan organik. Sampel tanah kering oven kurang lebih 10 gram dan lolos saringan no.10 ditempatkan pada tanur dengan kontrol suhu yang baik. Berat yang hilang dari sampel tanah sehubungan oksidasi bahan organik disebut LOI (\%), didapat melalui persamaan berikut ini:

$$
\text { LOI }(\%)=\left(\left(\text { Berat }_{105}-\text { Berat }_{440}\right) / \text { Berat }_{105}\right) \times 100
$$

Dimana:

LOI (\%) = jumlah bahan organik yang terdapat pada tanah

Berat $_{105}=$ berat tanah kering oven pada suhu $105^{\circ} \mathrm{C}$ selama $24 \mathrm{jam}$

Berat $_{440}=$ berat tanah setelah pemanasan pada suhu $440{ }^{\circ} \mathrm{C}$ selama waktu tertentu.

Suhu $440{ }^{\circ} \mathrm{C}$ pada persamaan ini berdasarkan ASTM D2974 Metode C. Pada suhu ini diharapkan kehilangan berat mengalami keadaan konstan.

\subsection{Metode Hydrogen Peroxide $\left(\mathrm{H}_{2} \mathrm{O}_{2}\right)$}

Metode Hydrogen peroxide $\left(\mathrm{H}_{2} \mathrm{O}_{2}\right)$ didasarkan pada pencernaan bahan organik oleh larutan alkali. Sampel tanah di uji dengan $10 \mathrm{ml}$ dari 30\% atau 50\% larutan Hydrogen peroxide $\left(\mathrm{H}_{2} \mathrm{O}_{2}\right)$ pada suhu di bawah $110^{\circ} \mathrm{C}$ untuk mengoksidasi bahan organik. $\mathrm{H}_{2} \mathrm{O}_{2}$ secara kontinyu ditambahkan pada sampel tanah sampai berhenti mengeluarkan gelembung, saat itulah pencernaan dianggap selesai. Sampel lalu dikering oven pada suhu $105^{\circ} \mathrm{C}$, jumlah bahan organik diperkirakan secara gravimetri melalui berat yang hilang.

$$
\operatorname{SOM}(\%)=\left(\text { Berat }_{\text {hilang }} / \text { Berat }_{\text {asli }}\right) \times 100
$$

Soil Organic Matter content/SOM (\%) adalah kandungan bahan organik tanah. Pencernaan Hydrogen peroxide $\left(\mathrm{H}_{2} \mathrm{O}_{2}\right)$ adalah metode yang mudah dan cepat untuk menentukan jumlah kandungan organik pada tanah.

\subsection{Uji Colorimetric}

Uji colorimetric adalah uji yang digunakan untuk mendeteksi adanya bahan organik dalam agregat halus yang digunakan pada campuran beton. Uji tersebut mengacu pada standar AASHTO T 21-05 dan ASTM C 40-04. Prinsip kerja uji ini adalah 
membuat ekstrak humus yang mewakili bagian terbesar bahan organik dari tanah menggunakan Natrium hidroksida $(\mathrm{NaOH})$. Sampel tanah kering udara yang lolos saringan no.10 dimasukan ke dalam botol gelas sebanyak 130 ml. Larutan $\mathrm{NaOH} 3 \%$ $(0.75 \mathrm{M})$ ditambahkan sampai botol gelas terisi $200 \mathrm{ml}$. Botol ditutup dan dikocok lalu dibiarkan selama 24 jam. Setelah 24 jam, warna cairan supernatant dihubungkan terhadap adanya material organik. Warna cairan supernatant dibandingkan dengan pelat warna standar bahan organik no.3. Bila lebih terang dari warna no.3 maka tanah tidak mengandung materi organik, bila lebih gelap tanah mengandung materi organik. Warna cairan supernatant lebih gelap bila materi organik $>3 \%$.

\begin{tabular}{|c|c|}
\hline ASTM Clay (soil 10) with 1.0\% Organic Matter & ASTM Clay (soil 10) with 1.3\% Organic Matter \\
\hline & \\
\hline & \\
\hline & \\
\hline
\end{tabular}

Gambar 8. Hasil colorimetric pada tanah organik buatan (ASTM C-40, 2004)

\section{PEMBAHASAN SIFAT FISIS TANAH}

Pengaruh bahan organik terhadap properti tanah telah diteliti secara luas. Keberadaan material organik mempunyai peran kritis dalam praktek rekayasa, karena selalu diasosiasikan dengan kadar air sangat tinggi, specific gravity rendah, kompresibilitas tinggi, koefisien creep tinggi dan karakteristik kekuatan yang buruk.

\subsection{Index Properties Tanah Organik}

Kazemian et al., 2011b mengumpulkan data properti fisis dan kimiawi tanah organik dan gambut dari berbagai penelitian yang telah terpublikasi sebelumnya. (Tabel 8. 8).

\section{Kadar Air}

Tanah organik umumnya mempunyai kadar air sangat tinggi, dengan rentang 125\%-1600\% bahkan untuk gambut serat bisa mencapai $2500 \%$. Kadar air lebih kecil dari $500 \%$ umumnya mengindikasikan adanya fraksi mineral dalam gambut. 


\section{Kadar Abu}

Kadar abu adalah presentase material kering yang tersisa dari bahan non-organik setelah pembakaran yang terkontrol. Tanah organik umumnya memiliki kadar abu antara $0.1-45 \%$ dari volumenya.

Tabel 8. Properti fisik dan kimiawi tanah organik (Kazemian et al., 2011b)

\begin{tabular}{|c|c|c|c|c|c|c|}
\hline Peat type & $\begin{array}{l}\text { Natural water } \\
\text { content }(w, \%)\end{array}$ & $\begin{array}{l}\text { Bulk density } \\
\left(\mathrm{Mg} \mathrm{m}^{-3}\right)\end{array}$ & $\begin{array}{l}\text { Specific gravity } \\
\left(G_{s}\right)\end{array}$ & Acidity $(\mathrm{pH})$ & Ash content (\%) & Reference \\
\hline Fibrous-woody & 484909 & - & - & - & 17 & Colley (1950) \\
\hline Fibrous & 850 & $0.95-1.03$ & $1.1-1.8$ & - & - & Hanrahan (1954) \\
\hline Peat & 520 & - & - & - & - & Lewis (1956) \\
\hline \multirow{3}{*}{ Amorphous and fibrous } & $500-1500$ & $0.88-1.22$ & $1.5-1.6$ & - & - & Lea and Brawner (1963) \\
\hline & $200-600$ & - & 1.62 & $4.8-6.3$ & $12.2-22.5$ & Adams (1965) \\
\hline & $355-425$ & - & 1.73 & 6.7 & 15.9 & \\
\hline Amorphous to fibrous & 850 & - & 1.5 & - & 14 & Keene and Zawodniak (1968) \\
\hline Fibrous & $605-1290$ & $0.87-1.04$ & $|.4|-\mid .7$ & - & $4.6-15.8$ & Samson and LaRochell (1972) \\
\hline Coarse fibrous & $613-886$ & 1.04 & 1.5 & 4.1 & 9.4 & Berry and Vickers (1975) \\
\hline Fibrous sedge & 350 & - & - & 4.3 & 4.8 & Levesqe et al. (1980) \\
\hline Fibrous sphagnum & 778 & - & - & 3.3 & I & \\
\hline Coarse fibrous & $202-1159$ & 1.05 & 1.5 & 4.17 & 14.3 & Berry (1983) \\
\hline Fine fibrous & 660 & 1.05 & 1.58 & 6.9 & 23.9 & $\mathrm{Ng}$ and Eischens (1983) \\
\hline Fine fibrous & 418 & 1.05 & 1.73 & 6.9 & 9.4 & \\
\hline Amorphous granular & 336 & 1.05 & 1.72 & 7.3 & 19.5 & \\
\hline Peat portage & 600 & 0.96 & 1.72 & 7.3 & 19.5 & Edil and Mochtar (1984) \\
\hline PeatWaupaca & 460 & 0.96 & 1.68 & 6.2 & 15 & \\
\hline Fibrous peat Middleton & 510 & 0.91 & 1.41 & 7 & 12 & \\
\hline Fibrous peat Noblesville & I73-757 & 0.84 & 1.56 & 6.4 & $6.9-8.4$ & \\
\hline Fibrous & $660-1590$ & - & $1.53-1.68$ & - & $0.1-32.0$ & Lefebvre et al. (1984) \\
\hline Fibrous & $660-890$ & $0.94-1.15$ & - & - & - & Olson and Mesri (1970) \\
\hline Amorphous Peat & $200-875$ & $1.04-1.23$ & - & - & - & \\
\hline Peat & $125-375$ & 0 & $1.55-1.63$ & $5-7$ & $22-45$ & Yamaguchi et al. (1985) \\
\hline Peat & 419 & I & 1.61 & - & $22-45$ & Jones et al. (1986) \\
\hline Peat & $490-1250$ & - & 1.45 & - & $20-33$ & Yamaguchi et al. (1987) \\
\hline Peat & $630-1200$ & - & $|.58-| .7 \mid$ & - & $22-35$ & Nakayama et al. (1990) \\
\hline Peat & $400-1100$ & $0.99-1.1$ & 1.47 & 4.2 & $5-15$ & Yamaguchi 1990 \\
\hline Fibrous & $700-800$ & $\sim 1.00$ & - & - & - & Hansbo (1991) \\
\hline Peat (Netherlands) & 669 & 0.97 & 1.52 & - & 20.8 & Termatt and Topolnicki (1994) \\
\hline Fibrous (Middleton) & $510-850$ & $0.99-1.1$ & $1.47-1.64$ & 4.2 & $5-7$ & Ajlouni (2000) \\
\hline Fibrous (James Bay) & $1000-1340$ & $0.85-1.02$ & $1.37-1.55$ & 5.3 & 4.1 & \\
\hline
\end{tabular}

\section{Bulk Density}

Bulk Density didefinisikan sebagai perbandingan berat tanah kering terhadap total volume. Bulk density adalah fungsi dari angka pori, kadar organik dan specific gravity. Tanah dengan kadar organik tinggi mempunyai bulk density rendah, terutama jika kadar serat tinggi. Serat pada tanah organik menciptakan lebih banyak struktur terbuka yang menghasilkan lebih banyak pori. Gambut amorphous dapat memiliki bulk density lebih besar dari $1200 \mathrm{~kg} / \mathrm{m}^{3}$, sedangkan gambut serat dapat memiliki bulk density serendah 840 $\mathrm{kg} / \mathrm{m}^{3}$.

\section{Void Ratio}

Angka pori tanah organik bervariasi dalam rentang 7-25. 


\section{Specific Gravity}

Specific gravity tanah dengan kadar organik tinggi umumnya dalam rentang 1.0 sampai 1.8. Kandungan mineral meningkatkan specific gravity, sehingga bila specific gravity lebih besar dari 2.0 mengindikasikan tanah mengandung banyak mineral dan dengan kata lain kadar organik rendah.

\section{Permeability}

Permeabilitas tanah organik sangat tinggi bergantung pada morfologi dengan rentang $10^{-5}-10^{-8} \mathrm{~cm} / \mathrm{s}$.

\section{Batas Atterberg}

Batas Atterberg meliputi batas cair (LL) dan batas plastis (PL). Batas Atterberg tanah organik tergantung pada dua karakteristik yang berlawanan, yaitu kapasitas penyerapan air yang tinggi dari bahan organik dan agregasi partikel dari substansi organik. Penyerapan air yang tinggi dari bahan organik meningkatkan batas Atterberg, tetapi kecenderungan bahan organik beragregasi fraksi mineral tanah cenderung menurunkan batas Atterberg. Secara umum batas cair dan batas plastis meningkat sejalan dengan kadar organik, karena kapasitas penyerapan air pada bahan organik seringkali melampaui pengurangan yang disebabkan bahan organik menginduksi agregasi. Uji batas plastis yang dilakukan pada tanah yang dikeringkan dengan suhu berbeda mengindikasikan batas tergantung dari metode pengeringan. Diduga suhu yang tinggi seringkali menghilangkan lebih banyak air bebas dibanding pada suhu yang lebih rendah.

\section{Potensi menyusut}

Susut pada tanah berkadar organik tinggi dapat signifikan, perubahan volume dapat mencapai $70 \%$ dari volume awal selama pengeringan. Penyusutan meningkat sejalan dengan kadar organik yang semakin besar.

\subsection{Pengaruh materi organik terhadap sifat fisis tanah}

\section{Kadar air vs kadar organik}

Amaryan (1993) menerangkan pengaruh sifat bahan organik terhadap kadar air seperti terlihat pada Error! Reference source not found.9. Semakin terhumuskan (besar pembusukan) suatu tanah organik maka kadar air semakin kecil. Hal ini berkaitan dengan bahan tumbuhan yang membusuk pada tanah organik, dari bahan fibric (fibrous) sampai 
sapric (amorphous). Jadi tanah dengan kandungan bahan organik yang sama tetapi derajat pembusukan besar, kadar airnya mengecil.

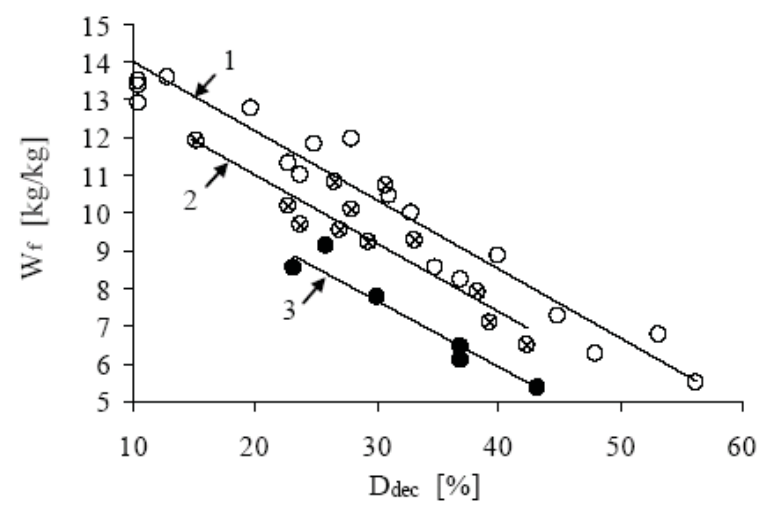

\section{Gambar 9. Pengaruh derajat penghumusan terhadap kadar air} (Amaryan, 1993)

Kazemian et al., 2009 membuat korelasi antara kadar air dengan kadar organik dari tanah-tanah organik di Malaysia Barat (Gambar 10.). Kadar air tanah yang diteliti berada dalam rentang 200\%-700\% dan kadar organik berada pada rentang 50\%-95\%. Kadar air memiliki kecenderungan meningkat sejalan dengan meningkatnya kadar organik mengikuti persamaan O.C (\%) $=0.06 \mathrm{~m}(\%)+54,34$.

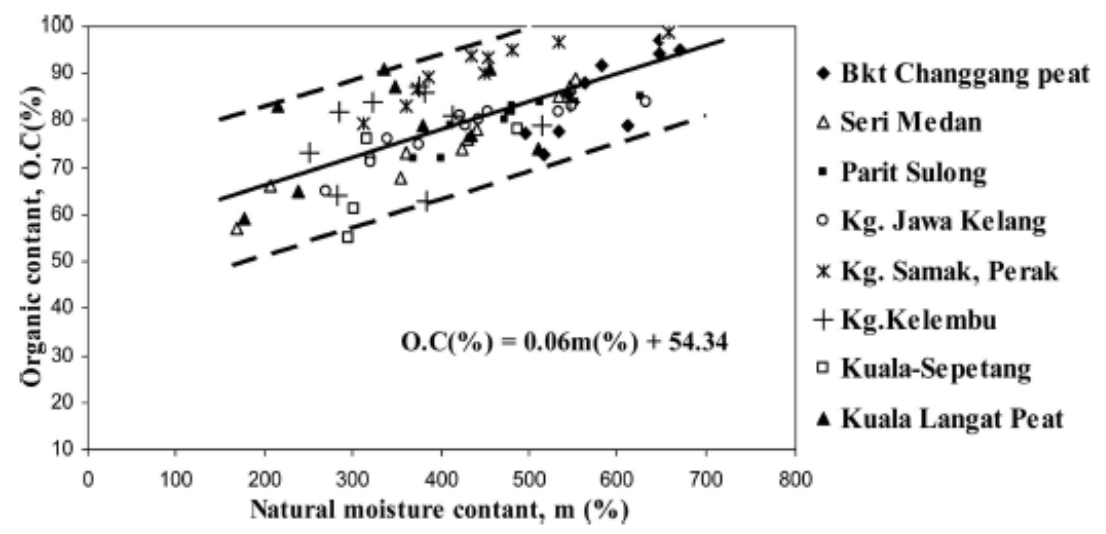

\section{Gambar 10. Kadar air vs kadar organik tanah Malaysia Barat} (Kazemian et al., 2009)

\section{Kadar air vs liquid limit}

Kazemian et al., 2009 membuat korelasi antara kadar air dengan batas cair (LL) dari tanah-tanah organik di Malaysia Barat (Gambar 11.). Kadar air tanah yang diteliti berada dalam rentang 200\%-900\% dan liquid limit berada dalam rentang 200\%-500\%. Liquid limit meningkat sejalan dengan meningkatnya kadar air. 


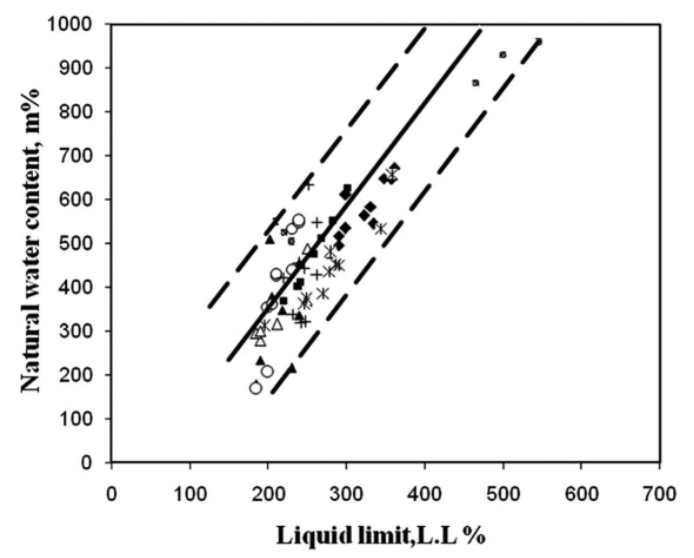

- Bkt Changgang peats

$\triangle$ Kuala Langat peats

- Kota Samarahan Peat

- Parit Sulong

o Seri Medan

* Kg.Samak,Perak.

+ Kg.Jawa

$\triangle$ Kuala-Sepetang

\section{Gambar 11. Liquid limit vs kadar air tanah organik di Malaysia Barat}

(Kazemian et al., 2009)

\section{Kadar organik vs liquid limit}

Kazemian et al., 2009 membuat korelasi antara kadar organik dengan liquid limit dari tanah-tanah organik di Malaysia Barat (Gambar 12.12). Liquid limit tanah yang diteliti berada dalam rentang 200\%-500\% dan kadar organik berada pada rentang 50\%95\%. Liquid limit meningkat sejalan dengan meningkatnya kadar organik mengikuti persamaan O.C $(\%)=0.175 \mathrm{LL}(\%)+20.37$. Sedangkan Skempton dan Petley (1970) menurunkan persamaan $\mathrm{LL}=0.5+5.0 \mathrm{~N}$, dimana $\mathrm{N}$ ialah LOI. Terlihat bahwa persamaan Skempton dan Petley tidak dapat diaplikasikan pada tanah organik di daerah tropis.

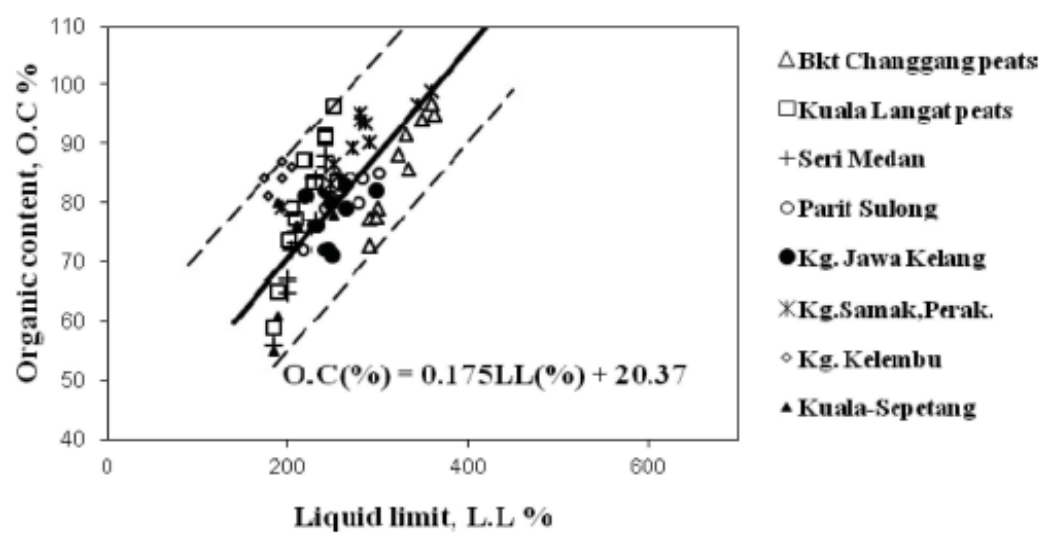

Gambar 12. Liquid limit vs kadar organik 


\section{Kadar air vs dry density}

Al-Raziqi et al., 2003 membuat korelasi antara kadar air dengan dry density dari tanah-tanah organik di Malaysia Barat (Gambar 12.13). Kadar air tanah yang diteliti berada dalam rentang $200 \%-700 \%$ dan dry density berada pada rentang $0.1-0.5 \mathrm{Mg} / \mathrm{m}^{3}$ memakai persamaan korelasi $\rho_{\mathrm{d}}=0.872(\mathrm{w}+0.317)^{-0.982}$, dimana $\rho_{\mathrm{d}}$ dalam $\mathrm{kN} / \mathrm{m}^{3}$ dan kadar air dalam \%. Korelasi tersebut diplot terhadap korelasi tanah di Belanda dan terlihat hasil plot berada dalam rentang tanah di Belanda.

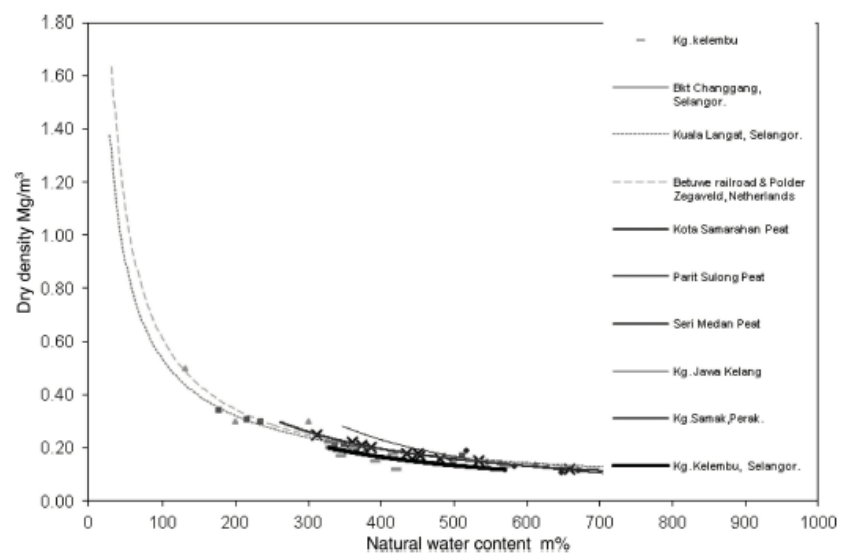

\section{Gambar 13. Kadar air vs dry density pada tanah Malaysia Barat} (Al-Raziqi et al., 2003)

Rahardjo, P.P. (2004), melakukan hal yang serupa pada tanah di Indonesia memakai persamaan korelasi $\rho_{\mathrm{d}}=0.872(\mathrm{w}+0.317)^{-0.982}$, dimana $\rho_{\mathrm{d}}$ dalam $\mathrm{kN} / \mathrm{m}^{3}$ dan kadar air dalam \% (Gambar 14.). Korelasi tanah di Indonesia diplot terhadap korelasi tanah di Belanda dan terlihat hasil plot berada dalam rentang tanah di Belanda.

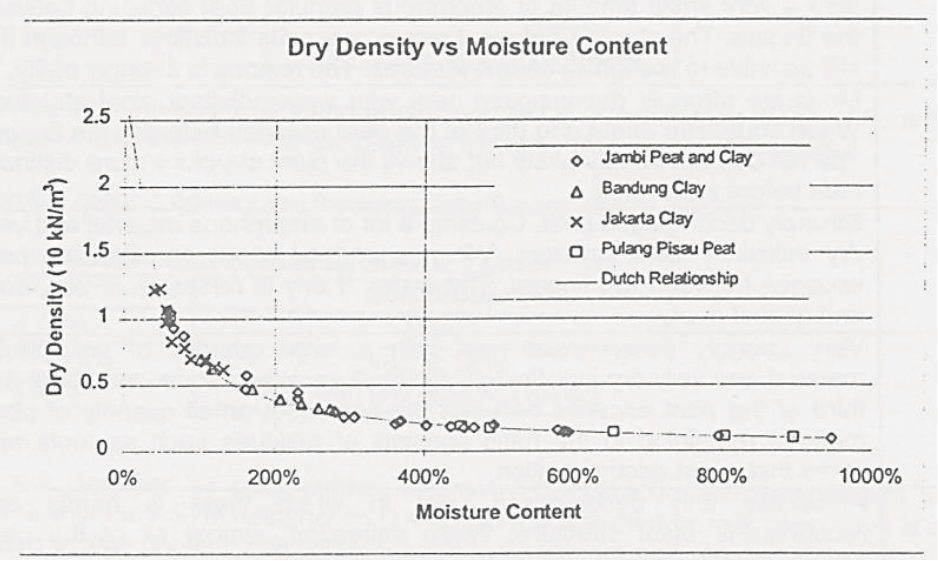

Gambar 14. Kadar air vs dry density pada tanah Indonesia (Rahardjo, P.P, 2004) 


\section{Specific gravity vs kadar organik}

Skempton dan Petley (1970) mengajukan korelasi antara specific gravity dan kadar organik mengikuti persamaan (6.1). Den Haan (1997) menyederhanakan persamaan Skempton dan Petley (1970) menjadi persamaan (6.2) untuk tanah-tanah di Belanda.

$$
\begin{aligned}
& \frac{1}{G_{s}}=\frac{1-1.04(1-N)}{1.4}+\frac{1.04(1-N)}{2.7} \\
& \frac{1}{G_{s}}=\frac{N}{1.365}+\frac{(1-N)}{2.695}
\end{aligned}
$$

Rahardjo, P.P. (2004), membuat korelasi antara specific gravity dengan kadar organik dari tanah-tanah organik di Indonesia (Gambar 11.15) memakai persamaan (6.2) Den Haan (1997). Hasil plot mengikuti kecenderungan persamaan (6.2), sehingga dapat disimpulkan secara umum tanah organik di Indonesia memiliki specific gravity yang sama dengan tanah pada daerah empat musim.

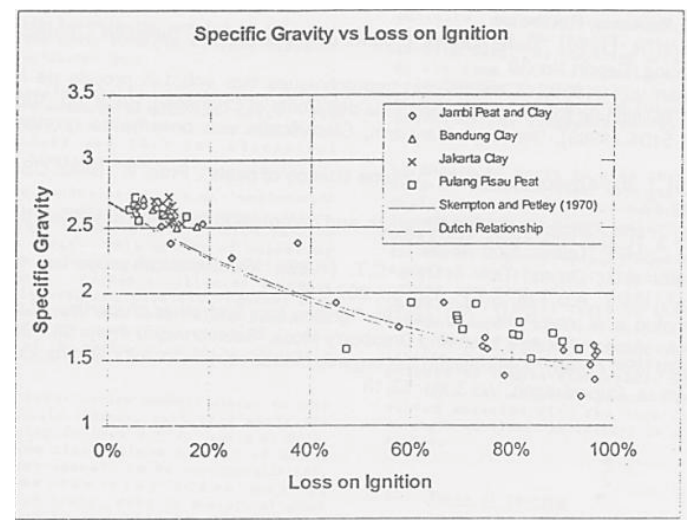

\section{Gambar 15. Kadar organik vs specific gravity tanah Indonesia (Rahardjo, P.P, 2004)}

Kazemian et al. (2009), melakukan hal yang serupa pada tanah di Malaysia Barat memakai persamaan korelasi Gs $=5.26(\text { O.C })^{-0.285}$ (Gambar 1Error! No text of specified style in document..). Terlihat Specific gravity mengecil sejalan dengan meningkatnya kadar organik. 


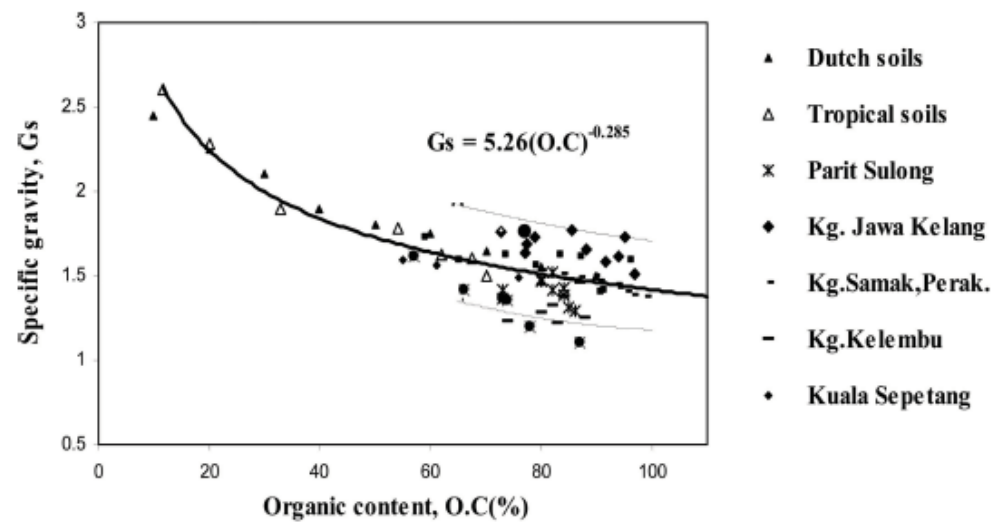

Gambar 1Error! No text of specified style in document.. Kadar organik vs specific gravity tanah Malaysia Barat

(Kazemian et al., 2009)

\section{Bulk density vs kadar organik}

Den Haan dan El Amir (1994) mengajukan korelasi antara bulk density dan kadar organik mengikuti persamaan (6.3) untuk tanah-tanah di Belanda.

$\gamma_{\text {sat }}\left(k N / m^{3}\right)=12.266-3.1560 C$

Rahardjo, P.P. (2004), membuat korelasi antara bulk density dengan kadar organik dari tanah-tanah organik di Indonesia (Gambar 11.) memakai persamaan (6.3) Den Haan dan El Amir (1994). Hasil plot mengikuti kecenderungan pada tanah di daerah empat musim sesuai dengan persamaan (6.3).

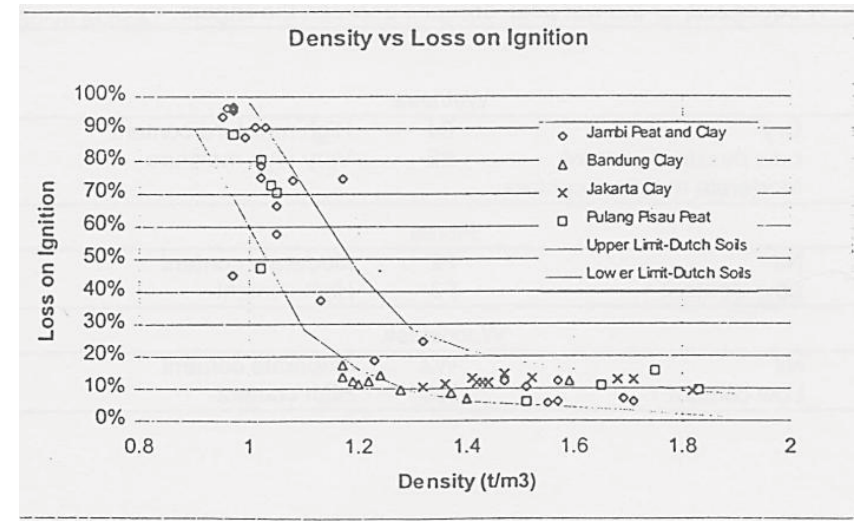

Gambar 17. Bulk density vs kadar organik pada tanah Indonesia (Rahardjo, P.P, 2004) 
Kazemian et al., 2009 melakukan hal yang serupa pada tanah di Malaysia Barat

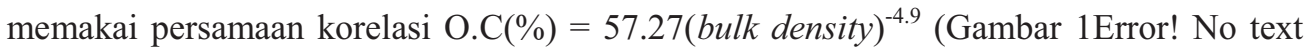
of specified style in document..8). Terlihat bulk density meningkat sejalan dengan menurunnya kadar organik.

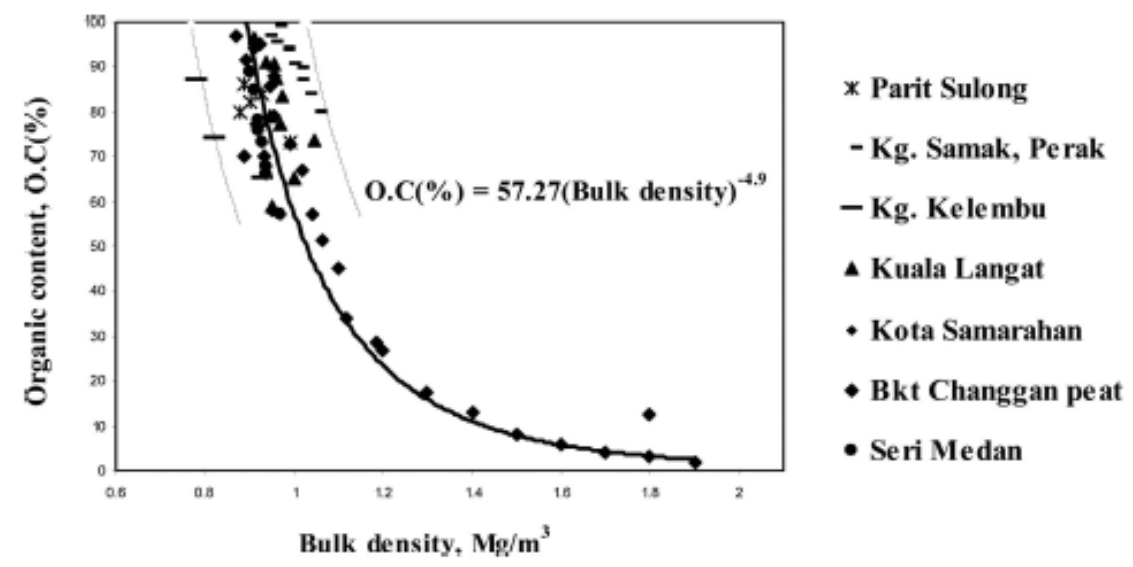

\section{Gambar 18. Bulk density vs kadar organik tanah Malaysia Barat (Kazemian et al., 2009)}

\section{KESIMPULAN}

Kesimpulan dari studi ini adalah sebagai berikut:

1. Pembangunan pada daerah atau lokasi yang secara geologi terletak pada cekungan/danau purba memerlukan identifikasi terhadap keberadaan tanah organik.

2. Identifikasi awal tanah organik di lapangan dapat menggunakan uji 'squeeze' yang sederhana dari Von Post, berbasis botani, dengan memperhatikan warna air dan keberadaan sisa tanaman. Sistem ini diadopsi dalam EN ISO14688-1:2002

3. Identifikasi tanah organik berdasarkan sistem klasifikasi ASTM D2487, AASHTO M145-91(2012), dilakukan secara visual berdasar bau, warna, dan tekstur. Metode ini bergantung pada penilaian pengamatan visual enjinir sehingga subyektif dan tidak tentu. Sistem klasifikasi FHWA berdasar nilai LOI membedakan tanah mineral, tanah organik maupun Highly organic soil. Sistem klasifikasi NEN 5104 (1989) berbentuk segitiga dapat digunakan untuk membedakan tanah organik dan gambut. Sistem klasifikasi Eurocode EN ISO14688-2:2004 tidak memiliki batasan yang jelas antara tanah mineral dan tanah organik.

4. Identifikasi tanah organik secara detail dapat dilakukan memakai Scanning Electron Micrographs (SEM). 
5. Identifikasi tanah organik in situ dapat dilakukan dengan uji Cone Penetration, baik CPT mekanis maupun CPTU, dan Dilatometer. Proses sampling tanah organik yang cukup sulit membuka peluang yang besar bagi pengujian pengujian in situ.

6. Penentuan kadar organik yang cukup mudah dilakukan di bidang Teknik Sipil adalah uji LOI dan $\mathrm{H} 2 \mathrm{O} 2$, namun membutuhkan peralatan laboratorium. Uji colorimetric digunakan untuk menentukan adanya material organik dengan menggunakan papan warna yang sederhana, ekonomis, mudah dibawa, namun tidak dapat menentukan jumlah kandungan organiknya.

7. Tanah organik dikenali dari warnanya, coklat gelap sampai hitam dengan konsistensi spongy dan bau organis serta kadang-kadang terlihat serat tumbuhan. Tanah digolongkan tanah organik bila kandungan bahan organik antara $25-75 \%$. Kandungan bahan organik $>75 \%$ dipakai untuk mengidentifikasi gambut. Tanah organik dapat dikenali dari propertinya antara lain nilai kadar air berkisar 125$1600 \%$, void ratio $7-25$, bulk density $0.84-1.23 \mathrm{t} / \mathrm{m}^{3}$, Specific gravity 1.1-1.8, Acidity (pH) 3.3-7.3, kadar abu 4.1-45, permeabilitas $10^{-5}-10^{-8} \mathrm{~cm} /$ detik, Batas cair (LL) 56-1500\%, Batas plastis 30-560\%. Batasan-batasan properti geoteknik untuk tanah organik umumnya masih tercampur dengan properti gambut.

8. Kadar air dan Liquid Limit meningkat, sementara Specific gravity dan bulk density mengecil sejalan dengan meningkatnya kadar organik.

\section{DAFTAR PUSTAKA}

1. AASHTO Standard M-145, Standard Specification for Classification of Soils and Soil-Aggregate Mixtures for Highway Construction Purposes.

2. Abdallah, I. Husein Malkawi, S. Alawneh Ahmed, and T. Abu-Safaqah O. 1999. "Effects of Organic Matter on the Physical and the Physicochemical Properties of an Illitic Soil,” Applied Clay Science, Vol. 14, pp.257-278.

3. Al-Raziqi, A. A., P., Huat, B.K.K. dan Munzir, H.A. 2003. Potential usage of hyperbolic method for predicition of organic soil settlement. Proc. 2nd International Conference on Advances in Soft Soils Engineering and Technology (eds. B. Huat et al.), Putrajaya, Malaysia, pp. 439-45

4. Amaryan, L.S., 1993. Soft Soils Properties and Testing Methods, Rotterdam:Balkema, 180p.

5. ASTM Standard D 2487 2000. Standard Practice for Classification of Soils for Engineering Purposes (Unified Soil Classification System), Vol. 04.08. 
6. ASTM Standard D 4427, 2007. Standard Classification of Peat Samples by Laboratory Testing, Vol. 04.08

7. Begemann, H.K.S. 1969. The Ducth static penetration test with the adhesion jacket cone. Lab, Grondmech. Delft, Meded., 12 (4), 69-100; 13 (1), 1-86

8. Chen, S. P., Lam, S. K. and Tan, Y. K. 1989. Geology of urban planning and development in Sarawak. Seminar on Urban Geology for Planners and Decision Makers Developing theUrban Environment. Geology Survey of Malaysia

9. Clayton, C.R.I. dan Jukes, A.W. 1978. A one point cone penetrometer liquid limit test?. Geotechnique, 28, 469-472

10. den Haan, E.J. 1997. An overview of the mechanical behaviour of peats and organic soils and some appropriate construction techniques. In: Proc.Conference on Advances in Understanding and Modelling the Mechanical Behaviour of Peat (eds. B.B.K. Huat \& H.M Bahia), Kuching, Sarawak. Pp. 17-45.

11. den Haan, E.J. dan El Amir L.S.F 1994. A simple formula for final settlement of surface loads on peat. In: Proc. Conference on Advances in Understanding and Modelling the Mechanical Behaviour of Peat (eds. E.J. den Haan et al.). Balkema, pp 35-48

12. Farrell, E.R. (2012) ICE Manuals of geotechnical engineering Volume I Geotechnical Engineering Principles, Problematic Soils and Site Investigation, The British Geotechnical Association

13. Huat, B.B.K. 2004. Organic and Peat Soils Engineering. 1st edn. University Putra Malaysia Press, Serdang, Malaysia

14. Huat, Bujang B.K., Arun Prasad, Afshin Asaidi and Sina Kazemian. 2014. Geotechnics of Organic Soils and Peat. CRC Press/Balkema. Leiden ,The Netherlands

15. Huang, P.T et al. 2009. Classification of organic soils. FHWA/IN/JTRP-2008/2.

16. ISO 14688 Part 1 Geotechnical Investigation and Testing - Identification and Classification of Soil - Identification and description. 2002.

17. ISO 14688 Part 2 Geotechnical Investigation and Testing - Identification and Classification of Soil - Principles for a classification. 2004.

18. Kazemian S., Asadi, A. Dan Huat, B.B.K. 2009. Laboratory study on geotechnical properties of tropical peat soils. International Journal of Geotechnics and Environment, 1, 69-79

19. Kazemian,S., Huat, B.B.K., Prasad,A., dan Barghchi,M., 2011. A State Review of Peat: Geotechnical Engineering Perspective. International Journal of the 
Physical Sciences. Vol. 6 (8), pp. 1974-1981. ISSN 1992-1950@2011. Academic Journals.

20. Kazemian, S., Prasad, A., Huat, B. B. K., Bolouri, B. J., Farah, N. A. A. and Thamer, A. M. .2011b. Influence of cement-sodium silicate grout admixed with calcium chloride and kaolinite on sapric peat. Journal of Civil Engineering and Management, 17(3), 309-18.

21. Leete, R. 2006. Malaysia's Peat Swamp Forests, Conservation and Sustainable Use. United Nations Development, Kuala Lumpur, Malaysia

22. MacFarlane, I.C., 1969. Muskeg Engineering Handbook, University of Toronto.

23. Marchetti, S. 2001. Flat Dilatometer Testing. International Conference on In Situ Measurement of Soil Properties and Case Histories. In Situ 2001

24. Mesri, G. and Ajlouni, M. 2007. Engineering properties of fibrous peats. Journal of Geotechnical and Geoenvironmental Engineering, 133(7), 850-66.

25. NEN 5104 1989. Nederlandse norm, Classificatie van onverharde grondmonsters. NNI Delft

26. Schmertmann 1978. Guidelines for Cone Penetration Test, Performance and Design. Federal Highway Administration Report no. TS-78-209, Washington D.C., 145 pgs

27. Skempton, A. W. dan Petley, D.J. 1970. Ignition loss and other properties of peats and clays from Avonmouth, King's Lynn and Cranberry Moss. Geotechnique, 20(4), 343-56

28. Rahardjo, P.P. 2004. SOFT SOIL ENGINEERING (LECTURE NOTES). POST GRADUATE PROGRAM, PARAHYANGAN CATHOLIC UNIVERSITY

29. Rahardjo, P.P., Halim Y., Sentosa L. Use of Dilatometer and Dual Dilatometer Test for Soft Soils and Peats. In Situ Testing and Case Histories in Indonesia. Geotechnical Engineering Consultant

30. Robertson, P.K., Campanella, R.G., Gillespie, D. And Greig, J. 1986. Use of piezometer cone data. Proceeding of the ASCE Speciality Conference In Situ '86: Useof In Situ Test in Geotechnical Engineering, Blacksburg, 123-80, American Society of Engineers (ASCE)

31. Wesley, L.D 2010. Mekanika tanah untuk tanah endapan dan residu. ANDI. 2012

32. Wijeyesekera, D.C. 2014. Significance of Micro-Mechanics in Geotechnical Engineering. Proceedings of Soft Soils 2014, Bandung, Indonesia, A7. 